\title{
A CADEIA DE CUSTÓDIA DA PROVA OBTIDA POR MEIO DE INTERCEPTAÇÕES TELEFÔNICAS E TELEMÁTICAS: MEIOS DE PROTEÇÃO E CONSEQUÊNCIAS DA VIOLAÇÃO
}

\author{
THE CHAIN OF CUSTODY OF EVIDENCE OBTAINED THROUGH \\ WIRETAPPING: PROTECTION MECHANISMS AND CONSEQUENCES \\ OF ITS VIOLATION
}

\author{
Lia Andrade de Souza \\ Instituto Brasiliense de Direito Público (Brasília, DF, Brasil) \\ Vinicius Gomes de Vasconcellos \\ Instituto Brasiliense de Direito Público (Brasília, DF, Brasil) \\ Recebimento: 18 ago. 2019 \\ Aceitação: 12 dez. 2019
}

\begin{abstract}
Como citar este artigo / How to cite this article (informe a data atual de acesso / inform the current date of access):
SOUZA, Lia Andrade de; VASCONCELLOS, Vinicius Gomes de. A cadeia de custódia da prova obtida por meio de interceptações telefônicas e telemáticas: meios de proteção e consequências da violação. Revista da Faculdade de Direito UFPR, Curitiba, v. 65, n. 2, p. 31-48, maio/ago. 2020. ISSN 2236-7284. Disponível em: https://revistas.ufpr.br/direito/article/view/68577. Acesso em: 31 ago. $2020 . \quad$ DOI:
\end{abstract} http://dx.doi.org/10.5380/rfdufpr.v65i2.68577.

\section{RESUMO}

O presente artigo almeja analisar, a partir de revisão bibliográfica e análise de casos jurisprudenciais de referência, a definição da categoria “cadeia de custódia” da prova no processo penal, verificando sua importância e as consequências de sua violação. Diante disso, pretende-se responder às seguintes questões: 1) — O que é a cadeia de custódia da prova no processo penal?, 2) — Qual é a importância de sua proteção? e, 3) - Quais mecanismos podem ser estabelecidos para a sua proteção e quais são as consequências de sua violação? Em termos jurisprudenciais, serão examinados o Habeas Corpus 160.662 do STJ e a Reclamação 32.722 do STF, em razão de sua representatividade na análise da temática da cadeia de custódia nos tribunais superiores brasileiros, ao passo que se trata de casos paradigmáticos de reconhecimento de quebra de cadeia de custódia das provas. Conclui-se que a cadeia de custódia da prova é dispositivo destinado a assegurar a fiabilidade do elemento probatório, impedindo interferências capazes de mascarar o resultado da atividade probatória, devendo-se prever mecanismos para sua proteção e consequências para a sua violação.

\section{PALAVRAS-CHAVE}

Cadeia de custódia. Interceptação telefônica e telemática. Confiabilidade da prova. Consequências da violação.

\section{ABSTRACT}

This article aims to analyze the chain of custody in the criminal procedure, through bibliographical and leading cases review, verifying its importance and the consequences in case of its violation. Then, the questions intended to be answered are: 1) - What chain of custody is in criminal procedure?, 2) What is the importance of its protection? and, 3) - What mechanisms can be used to protect the 
chain of custody and what are the consequences of its violation? About the leading cases, it will be analyzed the Habeas Corpus 160.662 of the Superior Court of Justice (STJ) and the Reclamação (Complaint) 32.722 of the Supreme Federal Court (STF), because they represent how the two Brazilian highest courts judge cases involving the theme of chain of custody. It is concluded that the chain of custody is a device to guarantee the evidence's reliability, avoiding interference capable of masking them, so mechanisms for its protection and consequences for its violation must be foreseen.

\section{KEYWORDS}

Chain of custody. Wiretapping. Evidence's reliability. Violation consequences.

\section{INTRODUÇÃO}

Em um cenário de consolidação de novos meios de investigação, em regra pautados por novas tecnologias, a existência de um sistema que garanta a rastreabilidade das provas é indispensável, ainda mais quando obtidas por métodos ocultos. Diante disso, mecanismos de controle de licitude probatória devem ser incorporados às técnicas investigativas, visando desestimular a prática de atos ilícitos na busca de provas e na persecução penal em geral. Desse modo, ressalta-se a importância do instituto da cadeia de custódia.

A cadeia de custódia, em síntese, é a fórmula garantidora da fidedignidade dos vestígios de prova coletados e examinados, garantindo autenticidade, rastreabilidade e confiabilidade. Assim, entende-se que esse conjunto de procedimentos técnicos deve ser observado por todos os profissionais que tenham sob sua responsabilidade o manejo e a conservação de elementos probatórios, desde a fase de investigação até a instrução processual.

Quando se trata de provas obtidas por métodos ocultos de investigação - neste caso a interceptação telefônica e telemática -, o papel da cadeia de custódia se torna ainda mais evidente. Por ser um meio de obtenção de prova que carece de previsão legal exaustiva sobre o procedimento que a produção deve obedecer (SANTORO; TAVARES; GOMES, 2017, p. 614), a técnica abre margens à manipulação de conteúdo probatório, possibilitando supressão e alteração por parte do investigador ou acusador. A seleção prévia e a apresentação de parcela das provas obtidas, sem observância do contraditório e ampla defesa, de boa ou má-fé, implica ilicitude da prova e a contaminação das provas dela decorrentes (ROSA, 2017, p. 445).

A manutenção integral de material obtido na interceptação telefônica é condição de validade da prova, sendo a rastreabilidade das provas fator essencial e primordial para um processo penal justo, regido pelo princípio da presunção de inocência. Assim, entende-se que, quando não há preservação de todo o material obtido por interceptação telefônica e telemática, há quebra na cadeia de custódia, pois inviabilizado o seu devido controle e o exercício do contraditório efetivo pela defesa. 
Consequentemente, os elementos probatórios produzidos deverão ser considerados ilícitos, assim como os deles derivados (PRADO, 2014b, p. 91).

O presente artigo, a partir de revisão bibliográfica e análise de casos jurisprudenciais de referência, almeja analisar a definição da categoria “cadeia de custódia” da prova no processo penal, verificando sua importância e as consequências de sua violação. Diante disso, pretende-se responder às seguintes questões: 1) — O que é a cadeia de custódia da prova no processo penal?, 2) — Qual é a importância de sua proteção? e, 3) - Quais mecanismos podem ser estabelecidos para a sua proteção e quais são as consequências de sua violação?

Em termos jurisprudenciais, o estudo examina o Habeas Corpus 160.662-RJ, impetrado perante o Superior Tribunal de Justiça e julgado em 2014, em que os impetrantes pugnaram a declaração de invalidade de provas e o consequente desentranhamento, em razão do extravio de parte das gravações obtidas via interceptação telemática ${ }^{1}$. No âmbito do Supremo Tribunal Federal, analisase a Reclamação 32.722, julgada em 2019, que analisou a necessidade de acesso aos arquivos originais de interceptação telemática, tendo em vista a existência de dúvidas sobre a sua autenticidade para utilização em persecução penal ${ }^{2}$. Tais precedentes foram selecionados em razão de sua representatividade na análise da temática da cadeia de custódia nos tribunais superiores brasileiros, ao passo que se trata de casos paradigmáticos de reconhecimento de quebra de cadeia de custódia das provas (PRADO, 2014b, p. 83).

\section{A CADEIA DE CUSTÓdIA COMO GARANTIDORA DA FIDEDIGNIDADE DAS PROVAS}

O processo penal é o instrumento de reconstrução histórica de fatos, sendo a prova o elemento que dá condições para o juiz verificar a existência ou não dos fatos narrados na acusação (LOPES JR., 2018, p. 341). No entanto, ressalta-se que o processo penal ocasiona uma "reconstrução histórica dos fatos” a partir de rastros do passado, de modo que a versão adotada refletirá tal história de um modo analógico, mas nunca integral, abrangente e inquestionável (KHALED JR., 2013, p. 591).

A função da prova no processo penal pode ser descrita como "instrumento cognitivo de reconstrução do fato passado e como elemento de persuasão do julgador em busca de seu convencimento” (VASCONCELLOS, 2018, p. 715). Assim, a prova, dentro do processo penal,

STJ, HC 160.662, 6 $6^{a}$ Turma, Rel. Min. Assussete Magalhães, DJe 17/03/2014.

2 STF, RCL 32.722, $2^{\text {a }}$ Turma, Rel. Min. Gilmar Mendes, j. 07/05/2019. 
integra os chamados modos de construção do convencimento do julgador, pois é a partir dela que ele “formará sua convicção e legitimará o poder contido na sentença” (LOPES JR., 2018, p. 342).

Em razão de as provas serem o elemento central de informação e verificação dos fatos passados, a sua autenticidade, fidedignidade e confiabilidade devem ser cristalinas e inquestionáveis. A prova conta com um viés legitimador do processo, pois é ela que estabelece parâmetros para que não se produza matéria fática não correspondente com a realidade apurada, afastando o subjetivismo das decisões judiciais (EDINGER, 2016, p. 239).

Considerando que boa parte das provas são obtidas fora do processo e permanecem em poder do Estado-acusação (MENEZES; BORRI; SOARES, 2018, p. 281), o "tema de provas exige a intervenção de regras de 'acreditação', pois nem tudo que ingressa no processo pode ter valor probatório; há que ser 'acreditado’, legitimado, valorado desde sua coleta até a sua produção em juízo para ter valor probatório” (LOPES JR., 2018, p. 412).

O cuidado com a prova produzida encontra fundamento nos princípios norteadores do processo penal: devido processo legal, ampla defesa, paridade de armas, presunção de inocência, contraditório e direito à prova lícita, visando garantir ao acusado condições de se defender e evitar arbítrios estatais. Além de tais princípios constitucionais, Geraldo Prado (2014a, p. 16-17) destaca os preceitos da "mesmidade” e da “desconfiança”. Entende-se por haver "mesmidade” quando é assegurado ao acusado que a prova avaliada em juízo é exatamente a mesma colhida preliminarmente - sendo a juntada de "parte de prova” colhida diferente de “mesma prova”. Já a “desconfiança” consiste em submeter a prova a um procedimento com critérios objetivos que dê credibilidade a ela, a fim de comprovar que corresponde ao que a parte alega ser (PRADO, 2014a, p. 16-17).

É importante destacar que o olhar atento sobre a produção de provas não possui o intuito de questionar a boa ou má-fé de agentes estatais, “mas sim de objetivamente definir um procedimento que garanta e acredite a prova independente da problemática em torno do elemento subjetivo do agente” (LOPES JR., 2018, p. 410).

Assim, consolida-se a necessidade de proteção da cadeia de custódia, fórmula garantidora da rastreabilidade dos elementos de prova coletados e examinados (ROSA, 2017, p. 445). A Portaria 82/2014, de 16 de julho de 2014, da Secretaria Nacional de Segurança Pública do Ministério da Justiça a define como “o conjunto de todos os procedimentos utilizados para manter e documentar a história cronológica do vestígio, para rastrear sua posse e manuseio a partir de seu reconhecimento até o descarte”3. Para a doutrina, a cadeia de custódia é como “um dispositivo dirigido a assegurar a

3 Disponível em: https://bit.ly/2FEuHtj. Acesso em: 23 jul. 2019. 
fiabilidade do elemento probatório, ao colocá-lo sob proteção de interferências capazes de falsificar o resultado da atividade probatória” (PRADO, 2014b, p. 86).

No Código de Processo Penal (CPP), embora não haja previsão explícita sobre a cadeia de custódia, dispositivos evidenciam a sua necessidade (BADARÓ, 2018, p. 526), como por exemplo o disposto no art. $6^{\circ}$, incisos I e III, que determina que a autoridade policial deverá dirigir-se ao local da prática da infração penal, providenciando para que não se alterem o estado e conservação das coisas, até a chegada dos peritos criminais, e colher todas as provas que servirem para o esclarecimento do fato e suas circunstâncias.

Assim, entende-se que a cadeia de custódia é todo o caminho percorrido pela prova, desde o momento de sua coleta até o trânsito em julgado ${ }^{4}$. Para que as provas sejam admitidas, após certificada a origem do vestígio, afirma-se que o desenvolvimento correto da cadeia de custódia se dá quando observadas as seguintes etapas: quem manejou o vestígio, o que fez com ele, e como o fez (EDINGER, 2016, p. 240). Fala-se em cadeia de custódia íntegra quando o procedimento é seguido à risca, sem interrupções ou falhas.

Portanto, a não rastreabilidade de uma prova gera dúvidas razoáveis acerca de sua idoneidade, pois se torna praticamente impossível identificar a existência de eventual vínculo entre uma prova aparentemente lícita e outra, anterior, ilícita (PRADO, 2014b, p. 79). Além disso, a falta de acesso à integralidade dos elementos probatórios colhidos inviabiliza o exercício efetivo do contraditório e do controle das afirmações aportadas por tais informações.

Nesse sentido, a manutenção da cadeia de custódia é de suma importância, pois é ela quem garante ao réu que a prova trazida pela acusação é a mesma que foi obtida na investigação (“mesmidade”), em observância aos procedimentos legais e sem alterações (“desconfiança”). Se assim não o for, haverá violação ao devido processo legal e ao contraditório.

É crucial que meios de obtenção de prova e o material colhido sejam preservados integralmente, principalmente quando se tratar de provas obtidas por meios ocultos, como a interceptação telefônica e telemática, em que a manutenção da cadeia de custódia se torna verdadeira condição de validade (MORAES, 2017, p. 131-132). O Estado-acusador, responsável pela investigação e pela persecução penal, precisa seguir critérios objetivos que assegurem credibilidade

\footnotetext{
4 "Muito sumariamente, a cadeia de custódia da prova é a corrente histórica ou sequência da posse de uma dada prova. A cadeia de custódia não se confunde com a prova da cadeia de custódia. A prova da cadeia de custódia consiste na reconstrução cronológica da corrente histórica da posse de uma dada prova, retratando-a desde sua geração até seu aporte nos autos, expondo cada um dos elos dessa corrente, por cujas mãos a detenção da prova foi passada” (DALLAGNOL; CÂMARA, 2016, p. 436).
} 
à prova. Não porque se presume má-fé dos agentes, mas tendo em vista que não se pode deixar o réu na

circularidade ingênua de quem, acreditando na "bondade dos bons" (Agostinho Ramalho Marques Neto), presume a legitimidade de todo e qualquer ato de poder, exigindo que se demonstre (cabalmente, é claro) uma conduta criminosa e os "motivos" pelos quais uma “autoridade” manipularia uma prova (LOPES JR., 2018, p. 410).

Trata-se de medida que tem a finalidade de impedir a manipulação indevida da prova e que reforça princípios constitucionais basilares do Estado Democrático de Direito. Não há o que se falar no mero franqueamento de acesso aos elementos probatórios pela acusação. É necessário que seja garantido à parte que aquela prova é idônea, cristalina, não alterada e original (MENEZES; BORRI; SOARES, 2018, p. 285). Só assim os princípios do contraditório e da ampla defesa poderão ser exercidos com efetividade.

Portanto, no que se refere à cadeia de custódia, é

dever do órgão acusador e da polícia judiciária a disponibilização de recursos e meios que, mais do que possibilitar mero acesso aos elementos de prova, tragam conteúdo íntegro, coerente e consistente - que possa ser rastreado e verificado, portanto -, dando azo a uma defesa efetiva a ser exercida (EDINGER, 2016, p. 243).

Se comprovada a falta de confiabilidade da prova, seja porque não há correspondência entre a prova colhida e aquela trazida ao feito, ou mesmo no que tange à sua idoneidade propriamente dita, haverá quebra na cadeia de custódia, o que implica ilicitude da prova, tema que será tratado adiante.

\section{A INTERCEPTAÇÃO TELEFÔNICA E TELEMÁTICA COMO MÉTODO OCULTO DE INVESTIGAÇÃO}

A importância da cadeia de custódia é evidente para a estruturação da teoria da prova na dogmática processual penal, no entanto, quando se fala em métodos ocultos de investigação, como a interceptação telefônica e telemática, o seu papel é protagonista.

A Constituição da República consagrou em seu art. 5, XII que "é inviolável o sigilo da correspondência e das comunicações telegráficas, de dados e das comunicações telefônicas, salvo, no último caso, por ordem judicial, nas hipóteses e na forma que a lei estabelecer para fins de investigação criminal ou instrução processual penal”. Tal previsão indica o sigilo das comunicações como um direito fundamental que abarca o direito à intimidade, vida privada, honra e imagem (ROSA, 2017, p. 496). Assim, o sigilo é a regra e a sua restrição, a exceção.

Demonstrando-se minuciosamente a necessidade, adequação e proporcionalidade em sentido estrito (ROSA, 2017, p. 499), em hipóteses de investigação criminal ou instrução processual 
penal, poderá ser autorizada judicialmente a interceptação telefônica, observados os requisitos do art. $2^{\circ}$ da Lei n. ${ }^{\circ}$ 9.296/96. Entende-se por interceptação telefônica a gravação de conversa, sem a ciência dos interlocutores, realizada por agente estatal, na forma prevista na referida lei.

Assim, é possível interceptar chamadas telefônicas, $e$-mails, comunicação por meio de rede social, mensagens de texto entre celulares, etc., sendo a comunicação fonte de prova, pois dela emerge a comprovação da prática de um delito ou então a confirmação da participação dos interlocutores (GOMES; MACIEL, 2013, p. 54). A decisão judicial que autorizar a medida deverá ser fundamentada e indicar a forma de execução da diligência, que não poderá exceder o prazo de quinze dias, renovável por igual tempo, se comprovada sua indispensabilidade ${ }^{5}$.

No tocante ao procedimento a ser seguido pelas autoridades investigativas durante interceptação telefônica, a Lei n. ${ }^{\circ}$ 9.296/96, que regulamentou o art. 5 , XII da CRFB/88, apenas determina que é competência do juiz que autorizar a medida definir a "forma de execução da diligência”. Essa omissão legislativa quanto ao adequado procedimento probatório tende a criar um ambiente propício a abusos e arbitrariedades, considerando os bens jurídicos envolvidos, "a menos que se definam mecanismos de estabelecimento prévio das 'regras do jogo', às quais todos os atores do sistema penal, inclusive o juiz, devam se submeter” (SANTORO; TAVARES; GOMES, 2017, p. 615).

A limitação dos meios de execução é competência do juiz autorizador da medida, não só na interceptação telefônica, como também em outros meios de obtenção de prova (ação controlada e infiltração de agentes), conforme previsto no art. $8^{\circ}$, $\S 1^{\circ}$ e art. $10^{\circ}$, caput, da Lei n. ${ }^{\circ} 12.850 / 13$. A Resolução 59 do Conselho Nacional de Justiça descreve detalhadamente em seu art. 10 o que o magistrado deve fazer constar na decisão autorizadora da interceptação, merecendo atenção especial os incisos VI e VII, que preveem importantes etapas da cadeia de custódia:

VI - os nomes das autoridades policiais responsáveis pela investigação e que terão acesso às informações; VII - os nomes dos funcionários do cartório ou secretaria responsáveis pela tramitação da medida e expedição dos respectivos ofícios, podendo reportar-se à portaria do juízo que discipline a rotina cartorária.

O interesse da defesa para que se estabeleçam critérios objetivos de atuação é evidente, mas essa limitação também é de suma importância para a acusação. Com parâmetros fixados, diminuem as possibilidades de eventuais excessos, o que posteriormente implicaria desvalorização de todo o material probatório obtido. Assim, “a sociedade não só ganha quando os culpados são condenados,

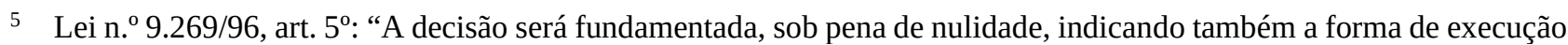
da diligência, que não poderá exceder o prazo de quinze dias, renovável por igual tempo uma vez comprovada a indispensabilidade do meio de prova”. 
mas ganha, também, quando os processos criminais são justos. Afinal, o próprio sistema de administração de Justiça perde sua legitimidade quando um acusado é tratado de maneira injusta.” (EDINGER, 2016, p. 245). Nesse sentido:

A delicada situação de uma investigação criminal não controlável pode conduzir, no extremo, a exercícios retóricos de desvalorização da própria investigação, quando, em realidade, ela ocupará lugar central em hipotética decisão condenatória fundada em depoimentos que analisam e avalizam o conjunto de elementos colhidos na investigação que eventualmente não estejam disponíveis para a defesa (PRADO, 2014b, p. 56).

Para melhor compreensão do tema, é importante expor, ainda que sucintamente, como os órgãos de investigação realizam uma interceptação telefônica. São três os principais sistemas de Tecnologia da Informação (TI) utilizados para recepção e armazenamento de dados interceptados: o Sistema Guardião (Dígitro Tecnologia Ltda.), o Sistema Sombra (Federal Tecnologia de Software Ltda. - EPP) e o Sistema Wytron (Wytron Technology Corp. Ltda.) (SANTORO; TAVARES; GOMES, 2017, p. 622).

No entanto, esses sistemas não funcionam sozinhos. A operacionalização se dá da seguinte forma: a operadora de telefonia, utilizando um sistema chamado Vigia, intercepta determinada informação e faz o desvio para um dos sistemas de TI (Guardião, Sombra ou Wytron). A sua atuação só é possível quando as operadoras de telefonia realizam a interceptação.

Assim,

os sistemas passivos de TI que recebem, monitoram e armazenam os dados interceptados são adquiridos e operados pelas autoridades públicas responsáveis pela investigação (ministério público, polícia federal, secretarias de segurança dos estados, etc.), ao passo que o Sistema Vigia tem como clientes exatamente as operadoras de telefonia (Claro, Oi, Vivo, Tim, Nextel, Embratel, GVT, Movistar) (SANTORO; TAVARES; GOMES, 2017, p. 624).

Ou seja, afirma-se que é a operadora quem de fato realiza a interceptação, pois os sistemas de monitoramento utilizados pelos órgãos de investigação são meramente passivos (SANTORO; TAVARES; GOMES, 2017, p. 624).

Segundo Geraldo Prado, o tratamento dado aos elementos obtidos por meio digital, diferenciado em relação àquele dispensado às provas materiais propriamente ditas (armas, documentos, drogas, etc.), que precisam permanecer intactas para o efetivo contraditório, traz um aspecto negativo ao processo penal, que pode se tornar apenas uma mera formalidade, já que há o cultivo da ideia - equivocada - de que as provas de mídia estão imunes à manipulação e corrupção (PRADO, 2014b, p. 59, 69, 73-74).

Santoro, Tavares e Gomes (2017, p. 626-629) descrevem de forma muito técnica diversas falhas nos sistemas de TI e, consequentemente, possibilidades de alteração em material obtido por 
interceptação telefônica: a) o sistema Guardião não bloqueia o recebimento do direcionamento de chamadas após a expiração do prazo; b) pode ocorrer apagamento de áudios no sistema Guardião quando for feita qualquer alteração de dados relacionados a um determinado áudio, ocorrendo o chamado apagamento lógico, e também quando o HD exceder a sua capacidade de armazenamento, pois os novos áudios começam a sobrescrever os antigos, se não realizado o procedimento de backup; c) o sistema Guardião permite o conhecimento de logs de eventos (informações estratégicas de execução do programa), logs de gravação (fornecem histórico de gravações e eventuais problemas no processo de conversão das gravações) e histórico de backups, porém: c1) o rastreamento dos logs só poderia ser feito até o backup, ou seja, a existência de material após o backup seria irrastreável; c2) não existem decisões judiciais que autorizem à defesa o acesso ao sistema de logs.

No cenário onde existe a clara possibilidade de falhas nos sistemas de armazenamento de dados, a preservação das fontes de prova é a única garantia que a defesa tem de que as provas trazidas ao processo são as mesmas obtidas na interceptação telefônica e telemática. A preservação é essencial para que se tenha uma cadeia de custódia íntegra, mecanismo capaz de garantir a idoneidade das provas e a paridade de armas entre a defesa e o Estado-acusação, “evitando que alguém seja julgado não com base no ‘mesmo’, mas no ‘selecionado’ pela acusação” (LOPES JR., 2018, p. 413).

\section{A IMPORTÂNCIA DA PRESERVAÇÃO DAS FONTES DE PROVA}

A importância da preservação integral das provas e dos meios de obtenção de prova se reflete no preceito da "mesmidade" mencionado no primeiro tópico, meio para assegurar ao acusado que a prova avaliada em juízo é exatamente a mesma colhida preliminarmente (PRADO, 2019).

Assim, entende-se que a juntada de "parte de prova” é diferente de "mesma prova”. Não se pode falar em “mesmidade” e cadeia de custódia íntegra quando “a prova é ‘filtrada’ pela autoridade policial ou órgão acusador, que traz para o processo (e submete ao contraditório diferido) apenas o que lhe interessa. Não é 'a mesma' prova colhida, mas apenas aquela que interessa ao acusador, subtraindo o acesso da defesa” (LOPES JR., 2018, p. 411). Nesse sentido:

\footnotetext{
Não cabe aos policiais executores da medida proceder a uma espécie de filtragem das escutas interceptadas. A impossibilidade desse filtro atua, inclusive, como verdadeira garantia ao cidadão, porquanto retira da esfera de arbítrio da polícia escolher o que é ou não conveniente ser interceptado e gravado. Valoração, e eventual exclusão, que cabe ao magistrado a quem a prova é dirigida (EDINGER, 2016, p. 250).
}

O direito ao contraditório sob a ótica do Estado de Direito é amplo e, portanto, "não está limitado ao conjunto de informações que a acusação (ou a polícia) disponibilizam ao juízo e à defesa” 
(PRADO, 2014b, p. 41). Tratando-se de interceptação telefônica, a necessidade de um efetivo contraditório é ainda mais importante, pois "não há contraditório no ato de formação da prova. O contraditório operará, com exclusividade, por ocasião do ingresso do elemento probatório no processo” (PRADO, 2014b, p. 16-17). Ou seja, não há garantia de contraditório àqueles elementos não juntados aos autos.

Aury Lopes Jr. (2018) afirma que só se tem um contraditório efetivo com informação e participação por meio da reação, requisitos cumulativos. No entanto, informação e reação por si sós não são suficientes, senão em igualdade de condições de agir.

Assim o contraditório é, essencialmente [...], o conhecimento completo da acusação, o direito de saber o que está ocorrendo no processo, de ser comunicado de todos os atos processuais. Como regra, não pode haver segredo (antítese) para a defesa, sob pena de violação ao contraditório (LOPES JR., 2018, p. 364).

É evidente, portanto, que o processo penal, como instrumento de limitação da persecução penal em um Estado Democrático de Direito, só se legitima quando há espaço garantido para o contraditório (ROSA, 2017, p. 357).

Segundo Geraldo Prado (2014b), há uma grande diferença - conceitual e prática - entre o que a acusação apresenta no processo, que servirá de condição e limitação para a decisão, e os elementos informativos colhidos pelas agências públicas de repressão. Isso porque "estes elementos são aptos a indicar à defesa a correção ou incorreção da trajetória da própria persecução penal, de modo a preparar-se para resistir à pretensão acusatória sob as mais variadas formas.” (PRADO, 2014b, p. 41).

Dessa forma, é absolutamente imprescindível que se tenha,

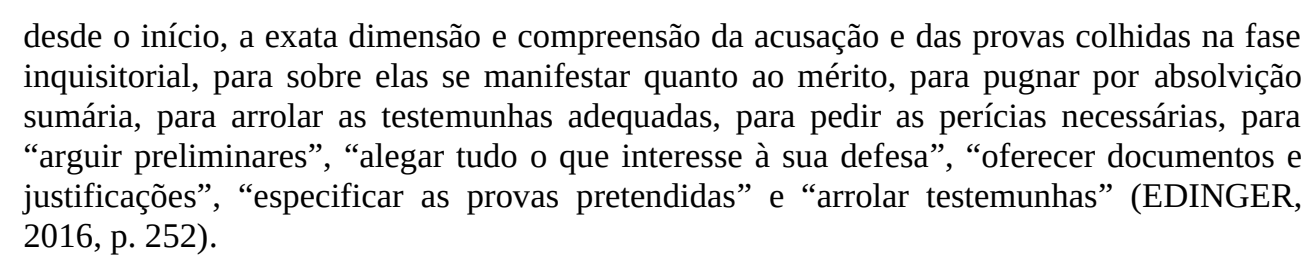

Assim, para que se tenha uma cadeia de custódia íntegra é necessário que as fontes de prova sejam preservadas em sua integralidade, bem como seja garantido o acesso amplo pelas partes (MENEZES; BORRI; SOARES, 2018, p. 290). Tal entendimento é corroborado pela Súmula Vinculante 14 do STF, que assegura ao defensor o acesso a todos os elementos relacionados ao exercício do direito de defesa: 
É direito do defensor, no interesse do representado, ter acesso amplo aos elementos de prova que, já documentados em procedimento investigatório realizado por órgão com competência de polícia judiciária, digam respeito ao exercício do direito de defesa.

O Estado-acusação, na figura da polícia judiciária e do Ministério Público, detém com exclusividade o poder de obter provas por meio de interceptação telefônica e telemática. Assim, filtrar provas e impedir o acesso às fontes de prova impede que eventuais ilegalidades sejam identificadas. Limitar o controle de legalidade apenas às provas apresentadas pelo acusador em juízo é insuficiente, pois dificilmente o autor de "ilicitudes probatórias permitiria a chegada ao processo de traços das referidas ilicitudes.” (PRADO, 2014b, p. 48).

A licitude probatória está diretamente ligada à sua rastreabilidade. Com o conhecimento da integralidade dos elementos probatórios, torna-se viável traçar a sua ligação com as fontes de prova e consequentemente fiscalizar a legalidade da atividade persecutória e eventuais provas ilícitas. Caso contrário, “o rastreamento das fontes de prova será uma tarefa impossível se parcela dos elementos probatórios colhidos de forma encadeada vier a ser destruída” (PRADO, 2014b, p. 41, 79).

Além disso, o acesso pleno às provas é medida garantidora da paridade de armas e a seletividade e uso arbitrário desequilibram a relação entre acusação e defesa. O Pacto de São José da Costa Rica dispõe, em seu art. 8 , 2, c, que “durante o processo, toda pessoa tem direito, em plena igualdade [...], à concessão do tempo e dos meios adequados para a preparação de sua defesa”. É evidente a necessidade de igualdade entre a acusação e a defesa, desde o início da persecução penal.

Assim, a paridade de armas desaparece diante da hipótese de “[...] a acusação, por si ou através da polícia, vir a dispor de amplo conjunto de informações e este acervo terminar sonegado à defesa, ainda que parcialmente, porque não foi devidamente resguardado ou até porque foi suprimido” (PRADO, 2014b, p. 57). Dessa forma, “qualquer tipo de filtro realizado na prova - quer seja por ocultação, destruição ou agregação de conteúdo -, é incompatível com o 'acesso amplo aos elementos de prova', justamente por corresponder à parte de um todo” (MACHADO; JEZLER JUNIOR, 2016, p. 8-9). Portanto:

A trapaça e a fraude no jogo processual encontram paralelo no doping esportivo, entendido como o ingrediente necessário para garantir o êxito, a glória e os aplausos, uma vez que os meios de comunicação tornam, do dia para a noite, jogadores em estrelas do espetáculo punitivo (ROSA, 2017, p. 361).

O denominado doping manipula o dispositivo do processo penal com práticas não democráticas que levarão a uma condenação ou absolvição dopada e suja (ROSA, 2017, p. 365). Assim, considera-se que a seleção unilateral de provas sem controle judicial é ato de má-fé, pois 
impede a parte de ter conhecimento sobre conteúdo que eventualmente possa servir para fundamentar suas teses de defesa e até mesmo sua absolvição (EDINGER, 2016, p. 243).

Por óbvio, tal ilegalidade não pode ser admitida em um processo penal em conformidade com os preceitos constitucionais e convencionais, sob pena de total deslegitimação da sanção penal imposta. Ressalta-se que “o Estado não pode praticar ilegalidades, omitir informações desfavoráveis, valer-se de métodos não autorizados em lei, potencializar inescrupulosamente elementos probatórios, mesmo que os agentes pensem que seja por bons motivos, aumentando a capacidade de se obter vitórias processuais” (ROSA, 2017, p. 362).

A fim de estabelecer regras para que haja um fair play no processo penal (ROSA, 2017, p. 365), o art. $9^{\circ}$ da Lei n. ${ }^{\circ}$ 9.296/96 é cristalino quanto à previsão de que a gravação que não interessar à prova apenas poderá ser inutilizada por decisão judicial, em incidente de inutilização, que deverá ser assistido pelo Ministério Público, possibilitada a presença do acusado ou seu representante legal. Esse controle de atividade probatória é de suma importância em um processo acusatório e "torna-se indispensável não apenas para assegurar a eficácia do contraditório como também para garantir que o processo, como entidade epistêmica, esteja eticamente fundamentado.” (PRADO, 2014b, p. 45).

O rito probatório não se trata de mero formalismo, é instrumento de garantia para o indivíduo e uma exigência democrática que deve ser seguida (GRINOVER; FERNANDES; GOMES FILHO, 2007, p. 155). Assim, o poder punitivo do Estado só é legítimo quando observado o princípio do devido processo legal, o que só pode ser assegurado se dado à parte o direito de conhecer integralmente as fontes de prova e o que delas surgiu (MAGALHÃES, 2015, p. 523).

\section{MECANISMOS DE PROTEÇÃO E CONSEQUÊNCIAS DA QUEBRA DA CADEIA DE CUSTÓDIA DA PROVA PENAL}

Assentadas as questões que norteiam o instituto da cadeia de custódia das provas no processo penal, cumpre discutir quais seriam seus mecanismos de proteção e as consequências de sua quebra. Para tanto, serão analisados dois julgados de tribunais superiores, apontados como paradigmas na temática aqui estudada. Primeiramente, no Habeas Corpus 160.662, julgado pelo STJ, definiu-se o rompimento da cadeia de custódia e as suas consequências ${ }^{6}$.

No HC impetrado perante o STJ, a defesa alega que não teve acesso a grande parcela de $e$ mails e áudios telefônicos interceptados, os quais foram unilateralmente apagados pela polícia sem que o réu pudesse analisá-los ou exercer qualquer espécie de controle e fiscalização. O extravio

6 STJ, HC 160.662, $6^{\text {a }}$ Turma, Rel. Min. Assussete Magalhães, DJe 17/03/2014. 
considerável de partes gerou áudios telefônicos não contínuos e mensagens eletrônicas não sequenciais, o que impediu os acusados de exercer de forma plena o contraditório e a ampla defesa, pois sem acesso às fontes de prova, tornou-se impossível refutar a tese acusatória.

Sustenta a defesa que após requerer acesso às provas e perceber que parte dos e-mails havia sido perdida, a autoridade policial informou que "não dispõe de equipamentos ou programas computacionais voltados à interceptação de e-mails” e por tal motivo o material interceptado estaria armazenado pelos provedores de internet ${ }^{7}$. No entanto, o provedor Embratel se manifestou no sentido de que não armazenou cópia dos e-mails interceptados, visto que “o Juízo determinou apenas e tão somente o desvio de qualquer tráfego de dados telemáticos para um e-mail a ser determinado por ofício pela Autoridade Policial, não tendo havido determinação ou autorização para que realizasse o armazenamento de tais dados ou informações.”8

Diante dos relatos de que a Polícia Federal e o provedor não possuíam o material, restou evidenciado que parte dele havia sido perdida. Além dos e-mails, a defesa aponta o extravio de parte das gravações obtidas mediante interceptação telefônica. Assim, por meio de um comparativo entre o conjunto de áudios gravados e a conta telefônica detalhada do investigado, a defesa concluiu que faltavam 68 ligações no material fornecido pela polícia. Em razão disso, a defesa alegou a ilicitude de todo o material probatório obtido com as interceptações telefônica e telemática.

Diante dos pedidos de declaração de invalidade da prova decorrente do afastamento do sigilo das comunicações - pelo desaparecimento parcial do material - e de desentranhamento integral do material colhido nas interceptações telemáticas e telefônicas - por constituir prova ilícita -, bem como de toda e qualquer prova derivada, a Sexta Turma do STJ entendeu que: a) foi extraviada parte das provas obtidas a partir das interceptações; b) é imprescindível a preservação da integralidade das provas, pois não podem servir apenas aos interesses do órgão acusador; c) a ausência da salvaguarda da integralidade do material colhido na investigação fere os princípios do contraditório e ampla defesa; d) para exclusão de material obtido por meio de interceptação, deve ser observado o disposto no art. 9º parágrafo único, da Lei 9.296/96; e) a disponibilização da integralidade de mídia, contendo o inteiro teor dos áudios e diálogos interceptados é reflexo da garantia da ampla defesa. Assim, decidiu por anular todas as provas produzidas nas interceptações telefônica e telemática - bem como eventuais provas ilícitas por derivação -, com o consequente desentranhamento integral do material que consta na ação originária.

7 Ofício 461/2009, Inicial do Habeas Corpus 160.662, p. 17.

8 Ofício Embratel, Inicial do Habeas Corpus 160.662, p. 18. 
O caso em análise é um exemplo claro de quebra da cadeia de custódia. Sobre essa problemática, considerando que a cadeia de custódia "exige o estabelecimento de um procedimento regrado e formalizado, documentando toda a cronologia existencial daquela prova [...]” (LOPES JR., 2018, p. 412), o descumprimento de tal fórmula implica perda de credibilidade da prova, consequências que deverão ser analisadas sob o viés da ilicitude. Pela imprescindibilidade de uma cadeia de custódia íntegra, Geraldo Prado leciona:

Com efeito, em um processo penal que se legitima a partir da verdade processual, hão de
vigorar providências que resguardem de fato o caráter cognitivo da persecução penal, que
não se justifica juridicamente quando fundada em impressões pessoais, sentimentos ou
valores pré-concebidos, a dispensar a incidência e operação de elementos informativos
obtidos de modo lícito (PRADO, 2014b, p. 87).

Como se sabe, não há espaço para provas ilícitas no processo penal brasileiro. A Constituição Federal, em seu art. 50, inciso LVI, prevê que são inadmissíveis no processo as provas obtidas por meios ilícitos. No mesmo sentido é a previsão do art. 157 do Código de Processo Penal, de que "são inadmissíveis, devendo ser desentranhadas do processo, as provas ilícitas, assim entendidas as obtidas em violação a normas constitucionais ou legais”.

O tratamento de ilicitude dado às provas cuja cadeia de custódia foi quebrada se dá em razão de o rompimento dos elos da cadeia levar à sua irrastreabilidade, o que gera dúvidas razoáveis acerca de sua idoneidade, afinal, “se eu desconheço a proveniência daquela prova, eu desconheço por quem aquela prova passou e o que foi feito com ela, nada impede que seja ela objeto de manipulação e seleção unilateral de provas [...]” (EDINGER, 2016, p. 256). Assim, “a constatação em um processo concreto de que houve supressão de elementos informativos colhidos nestas circunstâncias fundamenta a suspeição sobre a infidelidade de registros remanescentes e realça a ineficácia probatória resultante da quebra da cadeia de custódia” (PRADO, 2014b, p. 82).

Assim, os e-mails e gravações não descartados/extraviados não puderam ser objeto de qualquer valoração pelo magistrado, pois “[...] a supressão indevida de elementos informativos opera efeito impeditivo de emprego das informações remanescentes, que carecem de suficiência probatória.” (PRADO, 2014b, p. 87). O material restante está contaminado pela quebra, constituindo prova ilícita, ante a impossibilidade de exercer contraditório efetivo.

Já no âmbito do Supremo Tribunal Federal, o segundo caso que se pretende expor neste trabalho diz respeito aos mecanismos para assegurar a proteção à cadeia de custódia da prova penal. Em 7 de maio de 2019, a RCL 32.722, de relatoria do Min. Gilmar Mendes, por votação unânime foi julgada procedente na $2^{\mathrm{a}}$ Turma do STF para “assegurar à defesa o acesso aos arquivos originais das 
interceptações telemáticas, consoante fornecido pela operadora BlackBerry”, por violação à Súmula Vinculante 14 do $\mathrm{STF}^{9}$.

No caso concreto, houve a interceptação telemática de mensagens trocadas entre investigados por meio de aparelhos BlackBerry ${ }^{\circledR}$. Então, os dados foram enviados para a autoridade policial sem a identificação do emissor de cada mensagem, mas somente com a indicação de um número de usuário. Diante disso, houve a alteração dos cabeçalhos das mensagens para inserir os nomes dos supostos investigados, que teriam, na visão da polícia, enviados tais mensagens.

Em depoimentos prestados pelos policiais, afirmou-se que houve a alteração dos cabeçalhos das mensagens, mas comprovou-se que seria impossível a modificação do conteúdo das comunicações. Nos termos do voto do relator, por ter se estabelecido uma situação de dúvida, embasada em elementos concretos (depoimentos de policiais responsáveis pelos atos), sobre a confiabilidade dos dados apresentados pela autoridade investigativa em relação às comunicações interceptadas, “a incerteza sobre a fidedignidade das investigações impõe a adoção de medidas para proteção da cadeia de custódia das informações”. Portanto, determinou-se o acesso da defesa aos arquivos originais das interceptações telemáticas realizadas.

Tais julgados são paradigmáticos sobre o tema da cadeia de custódia das provas e colocam em discussão a importância do controle de ilicitude probatória, prática que serve de "desestímulo às agências repressivas quanto à tentação de recorrerem a práticas ilegais para obter a punição.” (PRADO, 2014b, p. 92). Portanto, primeiramente, deve-se assegurar meios para proteção da cadeia de custódia e, assim, da confiabilidade da prova, como no caso julgado pelo STF, em que se impôs o acesso da defesa aos arquivos originais. Basicamente, devem ser estruturados protocolos para assegurar o caminho da prova ao longo da coleta, conservação e análise das informações, além de sistema digitais para resguardar dados em meios informáticos.

Por outro lado, em uma situação de inviável manutenção da confiabilidade da cadeia de custódia, como no precedente do STJ, em que houve o desaparecimento de parte dos elementos de prova colhidos por meio de investigação oculto, a consequência será inevitavelmente a ilicitude de tais fontes. Ou seja, deve se estabelecer sistema em que a irregularidade na cadeia de custódia ocasione a inviabilidade de valoração da prova, visto que fragilizada a sua confiabilidade.

Em dezembro de 2019 foi aprovada a Lei 13.694/19, denominada originalmente como Pacote Anticrime. Embora apresentado pelo Ministério da Justiça e Segurança Pública, tal texto sofreu relevantes alterações ao longo do processo legislativo. E, sem dúvidas, um acréscimo

9 STF, RCL 32.722, 2a Turma, Rel. Min. Gilmar Mendes, j. 07/05/2019. 
importante relaciona-se à temática da cadeia de custódia no processo penal, tendo em vista a necessidade de estabelecimento de diretrizes e sistemas para assegurar a confiabilidade da prova, ou seja, garantir que os elementos colhidos para perícias na cena do crime, por exemplo, sejam guardados, conservados e manejados de um modo adequado e não alterados em tal processo.

Nesse sentido, a nova lei insere os artigos 158-A a F no CPP, definindo que cadeia de custódia é “o conjunto de todos os procedimentos utilizados para manter e documentar a história cronológica do vestígio coletado em locais ou em vítimas de crimes, para rastrear sua posse e manuseio a partir de seu reconhecimento até o descarte” (art. 158-A), envolvendo atos de reconhecimento, isolamento, fixação, coleta, transporte, recebimento, processamento, armazenamento e descarte de vestígios (art. 158-B).

A legislação introduz regras para resguardar a confiabilidade da prova. Por exemplo, determina que “todos os recipientes deverão ser selados com lacres, com numeração individualizada, de forma a garantir a inviolabilidade e a idoneidade do vestígio durante o transporte” (art. 158-D, § $1^{\circ}$ ). Além disso, “após cada rompimento de lacre, deve se fazer constar na ficha de acompanhamento de vestígio o nome e a matrícula do responsável, a data, o local, a finalidade, bem como as informações referentes ao novo lacre utilizado” (art. 158-D, § $4^{\circ}$ ).

Tais inovações legislativas são um evidente aprimoramento na regulamentação da matéria objeto deste estudo. Sem dúvidas, os novos dispositivos regulam de um modo detalhado os conceitos fundamentais, as etapas e as regras básicas para proteção da cadeia de custódia de vestígios no processo penal. Um ponto que pode ser destacado como ainda não tratado pela legislação diz respeito às consequências da violação da cadeia de custódia e das regras inserida no CPP. Em tal questão, deverão os tribunais assentar posicionamento no sentido da inutilidade do material em situações de evidente comprometimento de sua confiabilidade em razão de violação à cadeia de custódia.

\section{CONSIDERAÇÕES FINAIS}

A partir das considerações expostas neste artigo, retomam-se as questões que orientaram o seu desenvolvimento: 1) — O que é a cadeia de custódia da prova no processo penal?, 2) — Qual é a importância de sua proteção? e, 3) — Quais mecanismos podem ser estabelecidos para a sua proteção e quais são as consequências de sua violação?

1) A cadeia de custódia é uma fórmula de controle de licitude das provas, pois trata-se do conjunto de procedimentos utilizados para resguardar a cronologia dos vestígios, possibilitando seu rastreamento desde a sua coleta até o seu descarte. Ou seja, é uma espécie de dispositivo destinado a 
assegurar a fiabilidade do elemento probatório, impedindo interferências capazes de mascarar o resultado da atividade probatória.

2) Somente é possível falar em cadeia de custódia íntegra quando as fontes de prova são preservadas, a fim de proporcionar à defesa acesso amplo a todo o material obtido. Havendo qualquer tipo de filtragem das provas ou o extravio de parte delas, a cadeia de custódia se quebrará, pois ficará inviabilizado o rastreamento de eventuais ilicitudes e o exercício efetivo do contraditório. Portanto, trata-se de mecanismo fundamental para a estruturação dogmática da teoria da prova penal.

3) A partir dos precedentes jurisprudenciais analisados, assentou-se a importância do controle de ilicitude probatória. Primeiramente, deve-se assegurar meios para proteção da cadeia de custódia e, assim, da confiabilidade da prova, possibilitando o acesso da defesa aos arquivos originais de eventuais interceptações telefônicas e telemáticas. Por outro lado, em uma situação de inviável manutenção da confiabilidade da cadeia de custódia, como em caso de desaparecimento de parte dos elementos de prova colhidos por meio de investigação oculta, a consequência será inevitavelmente a ilicitude de tais fontes.

\section{REFERÊNCIAS}

BADARÓ, Gustavo. A cadeia de custódia e sua relevância para a prova penal. In: SIDI, Ricardo; LOPES, Anderson B. (org.) Temas atuais da investigação preliminar no processo penal. Belo Horizonte: D’Plácido, 2018. p. 517-538.

DALLAGNOL, Deltan M.; CÂMARA, Juliana A. S. R. C. A cadeia de custódia da prova. In: SALGADO, Daniel R; QUEIROZ, Ronaldo $P$. (org.). A prova no enfrentamento à macrocriminalidade. 2. ed. Salvador: Juspodivm, 2016. p. 435-471.

EDINGER, Carlos. Cadeia de custódia, rastreabilidade probatória. Revista Brasileira de Ciências Criminais, São Paulo, v. 24, n. 120, p. 237-257, maio/jun. 2016.

GOMES, Luiz Flávio; MACIEL, Silvio. Interceptação telefônica: comentários à Lei 9.269, de 24.07.1996. 2. ed. São Paulo: RT, 2013.

GRINOVER, Ada Pelegrini; FERNANDES, Antônio Scarance; GOMES FILHO, Antônio Magalhães. As nulidades no processo penal. 10. ed. São Paulo: RT, 2007.

KHALED JR., Salah H. A busca da verdade no processo penal. Para além da ambição inquisitorial. São Paulo: Atlas, 2013.

LOPES JR., Aury. Direito Processual Penal. 15. ed. São Paulo, Saraiva, 2018. 
MACHADO, Vitor Paczek; JEZLER JUNIOR, Ivan. A prova eletrônica-digital e a cadeia de custódia das provas: uma (re)leitura da Súmula Vinculante 14. Boletim IBCCRIM, São Paulo, ano 24, n ${ }^{\circ} 288$, nov./2016.

MAGALHÃES, Assusete. Quebra de sigilo de dados e das comunicações telefônicas: o dever estatal de preservação da fonte da prova. 2015. Disponível em: https://bit.ly/2PSIUoh. Acesso em: 23 jul. 2019.

MENEZES, Isabela A.; BORRI, Luiz A.; SOARES, Rafael J. A quebra da cadeia de custódia da prova e seus desdobramentos no processo penal brasileiro. Revista

Brasileira de Direito Processual Penal, Porto Alegre, vol. 4, n. 1, p. 277-300, jan./abr. 2018. http://doi.org/10.22197/rbdpp.v4i1.128.

MORAES, Ana Luisa Zago de. Prova penal: da semiótica à importância da cadeia de custódia. Revista Brasileira de Ciências Criminais, São Paulo, vol. 132, p. 117-138, jun./2017.

PRADO, Geraldo. A cadeia de custódia da prova no processo penal. São Paulo: Marcial Pons, 2019.

PRADO, Geraldo. Ainda sobre a quebra da cadeia de custódia das provas. Boletim do IBCCrim, São Paulo, n. 262, setembro de 2014a.

PRADO, Geraldo. Prova penal e sistema de controles epistêmicos: a quebra da cadeia de custódia das provas obtidas por métodos ocultos. São Paulo: Marcial Pons, 2014b.

ROSA, Alexandre Morais da. Guia do Processo Penal Conforme a Teoria dos Jogos. 4. ed. Florianópolis: Empório do Direito, 2017.

SANTORO, Antonio E. R.; TAVARES, Natália L. F.; GOMES, Jefferson C. O protagonismo dos sistemas de tecnologia da informação na interceptação telefônica: a importância da cadeia de custódia. Revista Brasileira de Direito Processual Penal, Porto Alegre, vol. 3, n. 2, p. 605-632, maio/ago. 2017. https://doi.org/10.22197/rbdpp.v3i2.76.

VASCONCELLOS, Vinicius Gomes de. A prova no processo penal: a importância da valoração do lastro probatório e de seu controle por meio recursal. Revista Eletrônica do Curso de Direito da UFSM, Santa Maria, v. 13, n. 2, p. 695-721, ago. 2018. http://doi.org/10.5902/1981369430012.

Lia Andrade de Souza

Bacharela em Direito

QLattes iD: http://lattes.cnpq.br/6364269192038797

E-mail: liaandrade1@hotmail.com

Vinicius Gomes de Vasconcellos

Doutor em Direito

QLattes iD: http://lattes.cnpq.br/9628659956663949

E-mail: vgomesv@gmail.com 